\title{
Intakes of key bone health nutrients in Caucasian and Asian women living in Southern England: baseline results from the Vitamin D, Food Intake, Nutrition and Exposure to Sunlight in Southern England (D-FINES) Study
}

\author{
Puikwan Lee, Ling Tan, Deborah David, Jaana Nurmi-Lawton, Warren Lee and Susan Lanham-New \\ University of Surrey, Guildford, UK
}

There are two key nutrients that encourage the optimisation of bone health throughout the life cycle: Ca, which is well-known for its health benefits; vitamin $\mathrm{D}$, which in the past few years has received increased attention that has shown that it may play a role in preventing several chronic diseases ${ }^{(1)}$. Vitamin D is produced freely by exposing skin to UV-B rays. However, populations in countries above latitude $37^{\circ} \mathrm{N}$ have no cutaneous vitamin D synthesis during winter seasons, and the further north a country is, the less sun it receives during summer seasons ${ }^{(2)}$. The UK population may be at risk of hypovitaminosis because the latitude of the UK is above $51^{\circ} \mathrm{N}$. This health issue has been confirmed in the 1958 British Birth Cohort Study ${ }^{(3)}$. However, there is currently no dietary reference value (DRV) for vitamin D for the age-group 4-64 years and accurate levels for dietary vitamin D required for optimisation of vitamin D status are not available. There have also been data to suggest that high $\mathrm{Ca}$ intakes and high dairy product consumption are associated with lower body weight and body fat distribution.

As part of the D-FINES Study seasonal data were collected for 242 Caucasian and seventy-two Asian women aged 19-70 years old over a period of 12 months. Women were randomly recruited either through general practitioners or through Asian community networks in Woking, Kingston and Thornton Heath. Data collected included: fasted blood samples for assessment of 25-hydroxyvitmin D status, parathyroid hormone and bone turnover markers; dietary intake, sunlight exposure; physical activity; bone density; skinfold thickness. The aim of the preliminary investigation, which considered baseline values for the 305 women, was to examine the competence of dietary intakes of $\mathrm{Ca}$ and vitamin $\mathrm{D}$ as well as their relationship with measures of body weight. The use of Ca and vitamin D supplements was an exclusion criteria for the study. Diet was analysed using Windiets 5 (Robert Gordon Institute, Aberdeen, UK) and body weight was determined and BMI calculated.

\begin{tabular}{|c|c|c|c|c|c|c|c|c|}
\hline & \multicolumn{4}{|c|}{ Caucasian women ( $n$ 242) } & \multicolumn{4}{|c|}{ Asian women ( $n$ 63) } \\
\hline & \multicolumn{2}{|c|}{ Post-menopausal ( $n$ 138) } & \multicolumn{2}{|c|}{ Premenopausal (n 104) } & \multicolumn{2}{|c|}{ Post-menopausal (n 31) } & \multicolumn{2}{|c|}{ Premenopausal (n 32) } \\
\hline & Mean & $\mathrm{SD}$ & Mean & $\mathrm{SD}$ & Mean & SD & Mean & $\mathrm{SD}$ \\
\hline Age (years) & 61.6 & 4.6 & 35.1 & 4.8 & 60.3 & 5.2 & 41.3 & 6.4 \\
\hline Weight (kg) & 69.8 & 12.4 & 67.5 & 11.9 & 71.0 & 15.2 & 65.0 & 12.8 \\
\hline Height (m) & 1.62 & 0.06 & 1.65 & 0.07 & 1.55 & 0.06 & 1.58 & 0.05 \\
\hline BMI $\left(\mathrm{kg} / \mathrm{m}^{2}\right)$ & 26.6 & 5.0 & $24.6^{* *}$ & 3.8 & 29.8 & 5.5 & 28.3 & 5.3 \\
\hline Energy $(\mathrm{kJ})$ & 7871 & 2659 & 8064 & 2215 & 7783 & 1867 & 9148 & 2244 \\
\hline Protein $(\mathrm{g})$ & 74.6 & 24.0 & 72.3 & 20.7 & 71.1 & 24.1 & 97.9 & 18.2 \\
\hline Fat $(\mathrm{g})$ & 73.0 & 32.8 & 75.4 & 23.9 & 78.3 & 25.1 & 74.7 & 25.9 \\
\hline $\mathrm{Ca}(\mathrm{mg})$ & 880 & 425 & 836 & 321 & 765 & 196 & 1022 & 147 \\
\hline Vitamin D $(\mu \mathrm{g})$ & 3.10 & 2.80 & $2.40^{*}$ & 2.40 & 1.85 & 1.47 & 2.27 & 2.00 \\
\hline
\end{tabular}

Values were significantly different from those for post-menopausal women within same ethnic group: $* P<0.05, * * P<0.01$.

As shown in the Table, women were divided into either post- or premenopausal groups according to their age. The BMI for pre- and post-menopausal groups were respectively 24.6 (SD 3.8) and 26.6 (SD 5.0; $P<0.01$ ) for Caucasian women and 28.3 (SD 5.3 ) and 29.8 (SD 5.5) for Asian women. The mean $\mathrm{Ca}$ intake was above the reference nutrient intake of $700 \mathrm{mg}$, but vitamin $\mathrm{D}$ intakes were low in both Caucasian and Asian groups, and were significantly lower in the premenopausal Caucasian group compared with the post-menopausal group. Energy intakes were reasonable, with limited under-reporting. Further work should examine the effect of season on dietary Ca and vitamin D intakes.

This work was funded by the Food Standard Agency (N05064). The views expressed are the authors' own. The authors are indebted to the following individuals for their help with subject recruitment: Mrs S Bano, Woking Khidmat Group; Mrs R Mahoon, Woking Asian Women's Association; Mrs R Hanjra and Mrs R Killedar, Islamic Resource Centre, Kingston; Mrs R Mahendran, Thornton Health Asian Association; Mrs F Smithers, College Road Surgery, Woking.

1. Scientific Advisory Committee on Nutrition (2007) Update on Vitamin D - Position Statement by the Scientific Advisory Committee on Nutrition 2007. London: The Stationery Office.

2. Holick MF (2002) Curr Opin Endocrinol Diabetes Obes 9, 87-98.

3. Hypponen E \& Power C (2007) Am J Clin Nutr 85, 860-888. 